\title{
Hotel Room Tax, Number of Accommodation and Original Local Government Revenue: Case Study West Sumatra Province, Indonesia
}

\author{
Sigit Sanjaya ${ }^{1}$, Ronni Andri Wijaya ${ }^{2}$ \\ \{sigitsanjaya@upiyptk.ac.id ${ }^{1}$, awheronniwijaya@upiyptk.ac.id ${ }^{2}$ \} \\ Faculty of Economic and Business, Universitas Putra Indonesia YPTK ${ }^{12}$
}

\begin{abstract}
This research aims to discover 1) The effect of hotel room tax on original local government revenue 2) The effect of hotel room tax on original local government revenue with the number of accommodations as moderating variables. There are 12 regencies and 7 municipalities numbers of population. Research data used for 6 years, $2014-2019$ period. The result shows: the hotel room tax has a positive and significant effect on original local government revenue. Secondly, the number of accommodations has no evidence as moderating variable for the relationship of hotel room tax with original local government revenue.
\end{abstract}

Keywords: Hotel Room Tax; Number of Accommodations; Original Local Government Revenue

\section{Introduction}

Regional autonomy policy can have a positive effect on the regions in terms of regional sovereignty to regulate their domains. When compared to a centralized system, this policy is considered to be superior because the regions are the main actors in development and are not side players. Since the implementation of regional autonomy, this policy has had a significant effect on the regions to maximize the existing potential due to the implementation of decentralization. Decentralization policies also have an impact on a country's economic growth [1].

Original Local Government Revenue (OLGR) is revenue that withheld based on local regulations in accordance with the legislation, for the purposes of financing their activities. OLGR consist of 3 main aspect, including local taxes, retributions, and income of regional government corporate and management of separated regional government wealth. One way to optimize local revenue is by maximizing tourism [2]; [3]; [4]; [5]. The relationship between the tourism industry and regional revenue is connected through the regional revenue channel and tax revenue sharing. The tourism sector can be a linkage for other product and service subsectors in increasing Gross Regional Domestic Revenue (GRDP) and local revenue itself.

In local tax revenue, in local tax revenue. Hotel tax plays an important role because it is the highest contributor in several municipalities and regencies. Although there are still many phenomena due to the constraints of the tax collection system that is applied to hotel taxes, considering self assesment system that requires honesty of the taxpayer itself. As a result, several regencies have not succeeded in exceeding the tax targets set. However, this indicates that the West Sumatra tourism sector has a positive influence on the development of West Sumatra in the future. 
Generally, there are 7 sectors that must be developed in tourism: accomodation, adventure and recreation, attractions, events and conference, food and beverage, tourism service and travel trade. Accomodation is a business that provides specialty services, it includes hotel, villa, cottage, camping, caravan stop, and other accommodation that are used for tourism purposes. In this research, we focus on the number of accommodation. The development of accommodation in West Sumatra in recent years has increased because local government make efforts to increase tourism. Developments can be seen from the increase in the number of accommodations that occur every year in the form of hotels and other accommodations.

Some previous studies have been conducted by [6]; [7]; [8] to test relationship between hotel room tax and local revenue. the relationship between number of hotels and local revenue has also been investigated by [9]; [10]. The difference between this study and previous research was on the decision to number of hotels as a moderating variable, then on the research object and the year of research, the sampling method was also different, because it would only take representative objects in tourism.

The theoretical framework was determined by reviewing some previous literatures. According to previous research, model for room hotel tax and original local government revenue from [6]; [11]; [12]; [13]. Model for room tax hotel, number of accomodations and original local government revenue from [14];[15]. Based on theory, previous literature and the definitions presented above, the following conceptual model are presented in Figure 1.

The conceptual model in Figure 1 generates 2 hypotheses will be tested in the study. Therefore, the hypotheses could be formulated as follows:

$H_{1}$ : $\quad$ Hotel room tax has significant effect on original local government revenue

$\mathrm{H}_{2}$ : $\quad$ Hotel room tax has significant effect on original local government revenue with number of accomodations as moderated variables

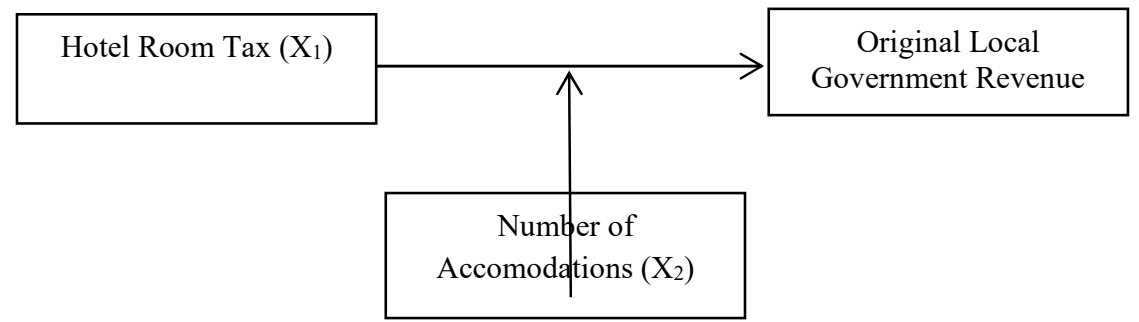

Fig.1. Conceptual Models

\section{Method}

The research approach used is the causality approach. Causal research is research that has the main goal of proving a causal relationship or relationship affecting the variables studied. The research data used are secondary data related to the studied variables obtained from the Central Statistics Agency (BPS) and the Department of Tourism during 2014-2019. The objects of this research are regencies and municipalities located in West Sumatra. The total population in this study was 19 , which consisted of 12 regencies and 7 municipalities. The sampling technique is using purposive sampling, where the selected sample is representing West Sumatra tourism according to the Department of Tourism. The samples are Padang city, 
Bukittinggi city, Payakumbuh city, South Pesisir regency and Mentawai Islands regency. sample selection can be seen in table 1

\begin{tabular}{lcc}
\multicolumn{3}{c}{ Table 1. Sample Selection } \\
\hline \multicolumn{1}{c}{ Criteria } & Total \\
\hline $\begin{array}{l}\text { Regencies and Municipalities in West } \\
\text { Sumatera }\end{array}$ & 19 \\
$\begin{array}{l}\text { Regencies and Municipalities that do not } \\
\text { yet represent tourism according to the }\end{array}$ & 14 \\
$\begin{array}{l}\text { Department of Tourism } \\
\text { Total Sample }\end{array}$ & 5 \\
\hline
\end{tabular}

Data analysis methods consist of descriptive analysis, determination of estimation models, classic assumption test, and moderated regression analysis by using EViews program. To test the hypotheses, the F-test and the t-test were performed.

The moderated regression analysis model used is as follows:

$\mathrm{Y}=\alpha+\beta_{1} \mathrm{X}_{1}+\beta_{2} \mathrm{X}_{2}+\beta_{3} \mathrm{X}_{1} \mathrm{X}_{2}$

Whereas:

$\mathrm{Y}=$ Original Local Government Revenue, revenue that witheld based on local regulations

$\mathrm{X}_{1}=$ Hotel Room Tax, imposition (collection) of taxes on each service provided by the hotel with payment

$\mathrm{X}_{2}=$ Number of Accomodations, the total number of hotels located in each regencies and municipalities in West Sumatra

\section{Result And Discussion}

Descriptive statistics are shown in table 2. Before conducting the analysis, several variables were transformed into $\log$ variables, hotel room tax $\left(\mathrm{X}_{1}\right)$ and original local government revenue $(\mathrm{Y})$. The hotel room tax $\left(\mathrm{X}_{1}\right)$ mean value is 9.216 with minimum value 7.22 and maximum value 10.98 while the Standard Deviaton (SD) obtained is 1.13436 . The number of accomodations $\left(\mathrm{X}_{2}\right)$ mean value is 47.0667 with minimum value 10.00 and maximum value 115.00 while the $\mathrm{SD}$ obtained is 31.97298. Original local government revenue (Y) mean value is 11.0760 with minimum value 10.56 and maximum value 11.74 while the SD 0.33517 .

Table 2. Descriptive Statistics

\begin{tabular}{cccccc}
\hline \multicolumn{7}{c}{ Table 2. Descriptive Statistics } \\
\hline Hotel_Room_Tax_X1 & 30 & 7.22 & 10.98 & 92160 & 113436 \\
Accomodation_X2 & 30 & 10.00 & 115.00 & 470667 & 3197298 \\
Revenue_Y & 30 & 10.56 & 11.74 & 110760 & .33517 \\
Valid N (listwise) & 30 & & & & \\
\hline
\end{tabular}


Determination of estimation models (Chow test and Hausman test), classic assumption tests (normality test and autocorrelation test) were performed. Chow test are shown in Table 3.

Table 3. Chow Test Result

\begin{tabular}{lccc}
\hline \multicolumn{1}{c}{ Effects Test } & Statistic & d.f. & Prob. \\
\hline Cross-section F & 37.226055 & $(4,22)$ & 0.0000 \\
Cross-section Chi-square & 61.501825 & 4 & 0.0000 \\
\hline
\end{tabular}

Based on Chow test in table 3, prob. value of Cross-section Chi-Square is $0.000<0.005$, which means that fixed effect is better than common effect to estimate the model. Next step is Hausman test. The result are shown in table 4 below.

Table 4. Hausman Test Result

\begin{tabular}{cccc}
\multicolumn{4}{c}{ Table 4. Hausman Test Result } \\
\hline Test Summary & Chi-Sq. Statistic & Chi-Sq. d.f. & Prob. \\
\hline Cross-section random & 10.457554 & 3 & 0.0151 \\
\hline
\end{tabular}

Based on Hausman test in table 4, prob. value cross-section random is 0.0151 , which means fixed effect is better than random effect to estimate the model. Based on the output of the Chow test and the Hausman test, the best model for estimating is fixed effect.

In classic assumption test, normality test use Jarque-Berra test. The output are shown in Figure 2 .

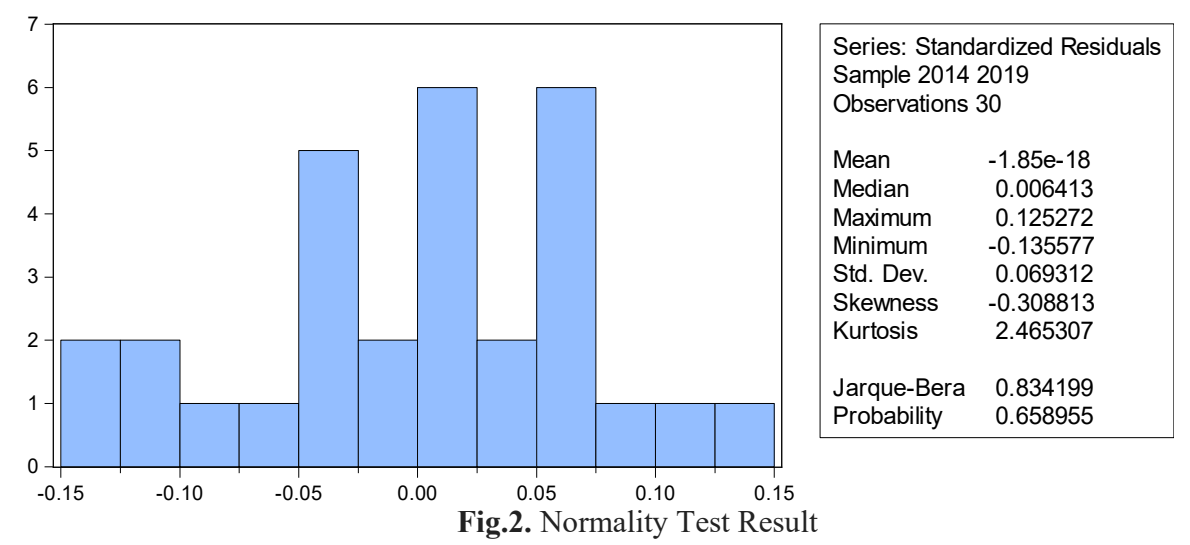

Based on normality test, Jarque-Berra prob. is $0.658955>0.05$, which means the data distribution is normal. Next step is autocorrelation test, the result are shown in table 5.

Table 5. Autocorrelation Test Result

\begin{tabular}{llll}
\hline R-squared & 0.957307 & Mean dependent var & 11.07667 \\
Adjusted R-squared & 0.943723 & S.D. dependent var & 0.335450 \\
S.E. of regression & 0.079578 & Akaike info criterion & -2.000980 \\
Sum squared resid & 0.139318 & Schwarz criterion & -1.627327 \\
Log likelihood & 38.01470 & Hannan-Quinn criter. & -1.881445 \\
F-statistic & 70.47251 & Durbin-Watson stat & 1.852250 \\
Prob(F-statistic) & 0.000000 & & \\
\hline
\end{tabular}


Based on autocorrelation test, Durbin - Watson stat is 1.852250 , where the value is between +2 and -2 , which means, there are no symptomps of autocorrelation. Based on classic assumption test (normality test and autocorrelation test), then this model is eligible for estimation moderated regression analysis.

Moderated regression analysis was performed to determine whether the relationship betwen two variables depends on (is moderated by) the value of a third variables. The $\mathrm{F}$ test and $t$ test using fixed effect estimation are shown in the table 6.

\begin{tabular}{lcccc}
\multicolumn{5}{c}{ Table 6. F test and t test result } \\
\hline \multicolumn{1}{c}{ Variable } & Coefficient & Std. Error & t-Statistic & Prob. \\
\hline C & 10.35152 & 0.302463 & 34.22415 & 0.0000 \\
HOTEL_TAX_X1 & 0.047905 & 0.034502 & 6.258491 & 0.0000 \\
ACCOMODATIONS_X2 & 0.017255 & 0.009073 & 1.901949 & 0.0704 \\
TAX_ACCOMODATIONS & -0.001183 & 0.000926 & -1.278334 & 0.2145 \\
\hline R-squared & 0.957307 & Mean dependent var & 11.07667 \\
Adjusted R-squared & 0.943723 & S.D. dependent var & 0.335450 \\
S.E. of regression & 0.079578 & Akaike info criterion & -2.000980 \\
Sum squared resid & 0.139318 & Schwarz criterion & -1.627327 \\
Log likelihood & 38.01470 & Hannan-Quinn criter. & -1.881445 \\
F-statistic & 70.47251 & Durbin-Watson stat & 1.852250 \\
Prob(F-statistic) & 0.000000 & & \\
\hline
\end{tabular}

Based on output in table 6. F test is statistically significant at prob. is $0.000<0.05$. Value of F statistic $>$ F table $(70.47251>2.96)$. Simultaneously, hotel room tax and number of accomodations have a significant effect on original local government revenue. Adjusted RSquare value is 0.943723 , whic means original local government revenue is influenced by independent variables (hotel room tax, number of accomodations) by $94.3723 \%$. The rest is influenced by other variables outside this research.

To test the effect of the independent variable on dependent variable partially, t-test was performed. For $\mathrm{H}_{1}$. Hotel tax prob. is $0.000<0.05$, $\mathrm{t}$ statistic $>\operatorname{tabel}(6.258491>1.703288)$. Hotel room tax has a positive and significant effect on original local government revenue. $\mathrm{H}_{1}$ is accepted. This research are line with previous studies by [6]; [11]; [12]; [13]. However, This research are not in line with previous studies by [7]. Hotel room tax has an important role in OLGR's growth contribution, especially in areas with well-known tourism. The number of visits that increase at the hotel both local and foreign tourists, or the duration of stay, will make tax revenue increase which will also increase OLGR. It is important for the government to conduct oversight of accommodations so that compliance and honesty in tax revenue increase.

For $\mathrm{H}_{2}$. Hotel room tax*number of accomodations prob. is 0.2145 . $>0.05$, t statistic < ttabel $(-1.278334<1.703288)$. the number of accomodations show no evidence as a moderating variable for the relationship of hotel tax with original local government revenue. $\mathrm{H}_{2}$ is rejected. This research are not in line with previous studies by [14]; [15]. In this study we have not found evidence of the number of accomodation strengthen the relationship between hotel room tax and original local government revenue. Increasing the number of hotels in various municipalities and districts did not contribute significantly to OLGR. Moreover, newly opened hotels use online travel companies and are small in scale The regional government needs to monitor hotels that have just been in business. Previous studies by [12] showed online travel companies (OTC) causing tax revenue losses. To prove this case in West Sumatra, further research is needed. 


\section{Conclusion}

This research aims to discover 1) The effect of hotel room tax on original local government revenue 2) The effect of hotel room tax on local government revenue with number of accomodation as moderating variables. Hotel room tax partially have a positive ad significant effect on original local government revenue. However, number of accomodations show no evidence as a moderating variable for the relationship of hotel room tax with original local government revenue.

Hotel room tax has an important contribution to original local government revenue. However, the increase in the number of accommodations is not accompanied by an increase in tax revenue. Local governments must be able to optimize tax revenue by supervising newly operating accommodations by not ignoring hotels that have been operating for a long time, in order to increase tax revenue.

\section{Acknowledgment}

All authors would like to thank Universitas Putra Indonesia YPTK and Yayasan Perguruan Tinggi Komputer for financial support. Any remaining errors are own.

\section{References}

[1] A. Feltenstein and S. Iwata, "Decentralization and macroeconomic performance in China: regional autonomy has its costs," J. Dev. Econ., vol. 76, no. 2, pp. 481-501, 2005.

[2] K. Archabald and L. Naughton-Treves, "Tourism revenue-sharing around national parks in Western Uganda: early efforts to identify and reward local communities," Environ. Conserv., pp. 135-149, 2001.

[3] M. J. Walpole and H. J. Goodwin, "Local economic impacts of dragon tourism in Indonesia," Ann. Tour. Res., vol. 27, no. 3, pp. 559-576, 2000.

[4] A. Blom, "The monetary impact of tourism on protected area management and the local economy in Dzanga-Sangha (Central African Republic)," J. Sustain. Tour., vol. 8, no. 3, pp. $175-189,2000$.

[5] A. Spenceley, S. Snyman, and A. Rylance, "Revenue sharing from tourism in terrestrial African protected areas," J. Sustain. Tour., vol. 27, no. 6, pp. 720-734, 2019.

[6] C. S. Bonham and B. Gangnes, "Intervention analysis with cointegrated time series: the case of the Hawaii hotel room tax," Appl. Econ., vol. 28, no. 10, pp. 1281-1293, 1996.

[7] J. Febriantoko and R. Mayasari, "17 Years Of Establishment Of Pagaralam As A Tourism City: How Is The Tourism Sector'S Ability To Increase Original Local Government Revenue?," Int. J. Sci. Eng. Sci, vol. 2, no. 9, pp. 61-64, 2018.

[8] Z. Fikri and R. M. Mardani, "Pengaruh Pajak Hotel, Pajak Restoran, Dan Pajak Hiburan Terhadap Pendapatan Asli Daerah Kota Batu (Studi Kasus Pada Dinas Pendapatan Kota Batu Tahun 2012-2016)," J. Ilm. Ris. Manaj., vol. 6, no. 1, 2017.

[9] D. C. Sutrisno, "Pengaruh jumlah obyek wisata, jumlah hotel, dan PDRB terhadap retribusi pariwisata kabupaten/kota di Jawa Tengah,” Econ. Dev. Anal. J., vol. 2, no. 4, 2013.

[10] J. Tendean, S. Palar, and K. Tolosang, "Pengaruh jumlah wisatawan terhadap pendapatan asli daerah (PAD) Kota Manado melalui pajak hotel sebagai intervening variabel," J. Berk. Ilm. Efisiensi, vol. 14, no. 3, 2014.

[11] J. Mak, "Taxing hotel room rentals in the US," J. Travel Res., vol. 27, no. 1, pp. 10-15, 1988.

[12] M. Mazerov and O. Expedia, "State and Local Governments Should Close Online Hotel Tax 
Loophole and Collect Taxes Owed," Cent. Budg. Policy Priorities, 2011.

[13] N. Gooroochurn and M. T. Sinclair, "Economics of tourism taxation: Evidence from Mauritius," Ann. Tour. Res., vol. 32, no. 2, pp. 478-498, 2005.

[14] S. W. Litvin, J. C. Crotts, C. Blackwell, and A. K. Styles, "Expenditures of accommodations tax revenue: A South Carolina study," J. Travel Res., vol. 45, no. 2, pp. 150-157, 2006.

[15] R. M. Bird, "Taxing tourism in developing countries," World Dev., vol. 20, no. 8, pp. 11451158, 1992. 